\title{
Cornelia de Lange syndrome with NIPBL mutation and mosaic Turner syndrome in the same individual
}

Jolanta Wierzba ${ }^{1 \dagger}$, María Concepción Gil-Rodríguez ${ }^{2+}$, Anna Polucha ${ }^{3}$, Beatriz Puisac $^{2}$, María Arnedo $^{2}$, María Esperanza Teresa-Rodrigo ${ }^{2}$, Dorota Winnicka ${ }^{3}$, Fausto G Hegardt ${ }^{4}$, Feliciano J Ramos ${ }^{2}$, Janusz Limon ${ }^{5}$ and Juan Pié , $^{26^{*}}$

\begin{abstract}
Background: Cornelia de Lange syndrome (CdLS) is a dominantly inherited disorder characterized by facial dysmorphism, growth and cognitive impairment, limb malformations and multiple organ involvement. Mutations in NIPBL gene account for about $60 \%$ of patients with CdLS. This gene encodes a key regulator of the Cohesin complex, which controls sister chromatid segregation during both mitosis and meiosis. Turner syndrome (TS) results from the partial or complete absence of one of the X chromosomes, usually associated with congenital lymphedema, short stature, and gonadal dysgenesis.

Case presentation: Here we report a four-year-old female with CdLS due to a frameshift mutation in the NIPBL gene (c.1445_1448delGAGA), who also had a tissue-specific mosaic 45,X/46,XX karyotype. The patient showed a severe form of CdLS with craniofacial dysmorphism, pre- and post-natal growth delay, cardiovascular abnormalities, hirsutism and severe psychomotor retardation with behavioural problems. She also presented with minor clinical features consistent with TS, including peripheral lymphedema and webbed neck. The NIPBL mutation was present in the two tissues analysed from different embryonic origins (peripheral blood lymphocytes and oral mucosa epithelial cells). However, the percentage of cells with monosomy $X$ was low and variable in tissues. These findings indicate that, ontogenically, the NIPBL mutation may have appeared before the mosaic monosomy $X$.

Conclusions: The coexistence in several patients of these two rare disorders raises the issue of whether there is indeed a cause-effect association. The detailed clinical descriptions indicate predominant CdLS phenotype, although additional TS manifestations may appear in adolescence.
\end{abstract}

Keywords: Cornelia de Lange syndrome, CdLS, NIPBL, Turner syndrome, TS, Monosomy X mosaicism, Mosaic 45,X/ 46,XX karyotype

\section{Background}

Cornelia de Lange syndrome (CdLS; OMIM 122470, 300590, and 610759) is an inherited congenital developmental disorder characterized by distinctive features including facial dysmorphism, growth and cognitive

\footnotetext{
* Correspondence: juanpie@unizar.es

${ }^{\dagger}$ Equal contributors

${ }^{2}$ Unit of Clinical Genetics and Functional Genomics, Departments of Pharmacology-Physiology and Pediatrics, Medical School, University of Zaragoza, and Institute of Health Sciences of Aragón, Zaragoza, Spain ${ }^{6}$ Unit of Clinical Genetics and Functional Genomics, Department of Pharmacology and Physiology, University of Zaragoza, Medical School, c/Domingo Miral s/n, Zaragoza E-50009, Spain

Full list of author information is available at the end of the article
}

impairment, limb malformations, hirsutism and the involvement of other organ systems with variable expressivity [1]. Prevalence estimates range from 1:62,000 to 1:45,000 live births [2]. To date, mutations in three genes have been identified in $\sim 65 \%$ of clinically welldefined CdLS cases, namely: NIPBL on chromosome $5 \mathrm{p} 13(60 \%), S M C 1 A$ on chromosome Xp11 and SMC3 on chromosome 10q25 (5\%) [3-6]. These three genes encode regulatory or structural components of the highly conserved Cohesin complex, which participates in chromosome segregation, DNA repair mechanisms, gene expression and chromosome conformation [7].

\section{Biomed Central}


Turner syndrome (TS) is a common chromosomal disorder, usually associated with short stature, gonadal dysgenesis, cardiovascular abnormalities, hearing loss, neck webbing and lymphedema; although a number of organ systems and tissues may also be affected to a lesser or greater extent [8]. TS affects about one in 2000 live born females and results from complete or partial absence of one of the $\mathrm{X}$ chromosomes, frequently accompanied by cell-line mosaicism, which may also be tissue-specific $[9,10]$.

Chromosomal rearrangements in individuals with CdLS have been reported over the years, involving 1-5, $7-14,17,18,21$ and X chromosomes [11]. To date, only four patients with CdLS have been reported to have sex chromosome anomalies: one male with $45, \mathrm{X} / 46, \mathrm{XY}$ mosaicism [12], one female with 45,X karyotype [13] and two females with mosaic 45,X/46,XX karyotypes $[14,15]$.

We report a female with CdLS, with an identified mutation in the NIPBL gene, and TS due to a mosaic $45, \mathrm{X} / 46$, $\mathrm{XX}$ karyotype. We present a detailed phenotype description focusing on the typical clinical features of CdLS and TS. Furthermore, we compare the phenotype of our patient to other reported cases with similar karyotype and an unknown or different genotype. Finally, we examine the significance of a possible association of both syndromes.

\section{Case presentation}

The patient is the first child of a healthy and unrelated 35-year-old father and a 37-year-old mother. There was no family history of congenital defects. She has a healthy younger brother. The girl was born at 35 weeks gestation by caesarean section due to placental insufficiency. Birth weight was $1.350 \mathrm{~kg}$, length $43 \mathrm{~cm}$ and head circumference $25 \mathrm{~cm}$ (all below the $3^{\text {rd }}$ centile for gestational age) (Table 1). Apgar score was 7 in the first minute and 9 at five minutes. Craniofacial dysmorphism included: microbrachycephaly, bitemporal narrowing distance, synophrys, arched eyebrows, long and irregularly placed eyelashes, depressed nasal bridge, anteverted nares, long and flat philtrum, thin upper lip, downslanting corners of the mouth, micrognathia, high arched and vaulted palate, low-set and posteriorly rotated ears, low posterior hairline, short and webbed neck and hirsutism (Figure 1A and B, Table 1). She had small hands and feet, lymphedema of the feet (resolved at two months of age), bilateral clinodactyly of the fifth finger, proximally placed thumbs, single palmar crease and hip dislocation (Figure 1B, D and E, Table 1). Additional neonatal findings included mild hypertonia, lack of the sucking reflex, congenital bilateral glaucoma, retinopathy, atrial and ventricular septal defect (ASD VSD) and mild pulmonary stenosis (PS) that did not require surgery. At two years of age gastroesophageal reflux disease (GERD) was suspected although it could not be confirmed. More detailed clinical description of the patient is provided in Table 1.

At the age of 3 years and 6 months (Figure 1C-E) her weight was $9.1 \mathrm{~kg}$, height $81 \mathrm{~cm}$ and head circumference $41 \mathrm{~cm}\left(\leq 50^{\text {th }}\right.$ centile on CdLS growth charts).Physical examination showed broad chest with widely spaced nipples, short sternum, bilateral cubitus valgus, limited elbow extension, small and hypoplastic nails and myopia. Developmental milestones were severely delayed. She was able to sit unsupported, but not to stand or walk. Speech was absent but she could follow simple instructions. The patient had autistic-like features with episodes of aggression and self-injurious behaviour. Mild bilateral sensorineural hearing loss was detected by auditory brainstem response (ABR). She had delayed bone age (Figure 1D) (Table 1). Biochemical, endocrine and metabolic studies were normal, except for high serum TG (triglyceride) levels $(232 \mathrm{mg} / \mathrm{dL}$; normal value range for TG levels is $<98 \mathrm{mg} / \mathrm{dL}$ ). Thyroid function tests (T3, T4, TSH) and celiac screen (IgA-TTG and IgA-EmA antibodies) were also normal.

\section{Methods and results Molecular analysis}

Blood samples and buccal smears were obtained after written informed consent, and genomic DNA was isolated from peripheral blood lymphocytes and oral mucosa epithelial cells by standard protocols. The entire coding region and flanking intron sequences of NIPBL (exons 2-47) were screened for mutations by bidirectional sequencing. The NIPBL reference sequence used was NM_133433. Parental genotypes were screened to assess whether the variant was de novo or inherited.

NIPBL mutational screening showed a de novo mutation in exon 9 (c.1445_1448delGAGA), which predicts a truncated protein p.R482NfsX20 (Figures 2A and B). To test whether the patient carries the NIPBL mutation in mosaic state, molecular analyses were performed on two tissues of different embryonic origins: peripheral blood lymphocytes (mesoderm) and epithelial cells from oral mucosa (ectoderm). The mutation-related peaks were similar in both tissues, ruling out widespread mosaicism (Figure 2A).

\section{Cytogenetic analysis}

Conventional cytogenetic analysis of metaphase chromosomes prepared from cultured peripheral blood lymphocytes was performed according to standard procedures using the GTG banding technique. Karyotype was $45, \mathrm{X} / 46$, XX, with $24 \%$ cells containing only one X chromosome 
Table 1 Clinical data for patients with typical features of CdLS and TS

\begin{tabular}{|c|c|c|c|c|c|c|c|}
\hline \multirow{2}{*}{\multicolumn{2}{|c|}{ Clinical findings }} & \multicolumn{2}{|c|}{$\begin{array}{l}\text { CdLS and } 45, X / 46, X X \\
\text { mosaicism [14] }\end{array}$} & \multicolumn{2}{|c|}{$\begin{array}{l}\text { CdLS (NIPBL mutation) and } \\
45, \mathrm{X} / 46, \mathrm{XX} \text { mosaicism } \\
\text { [this paper] }\end{array}$} & \multicolumn{2}{|c|}{$\begin{array}{c}\text { CdLS (SMC1A mutation) } \\
\text { and } 45, \mathrm{X} / 46, \mathrm{XX} \\
\text { mosaicism }[15]\end{array}$} \\
\hline & & $T S$ & $C d L S$ & $T S$ & $C d L S$ & $T S$ & $C d L S$ \\
\hline \multicolumn{8}{|c|}{ Birth parameters and growth } \\
\hline \multicolumn{2}{|c|}{ Birth weight $<10^{\text {th }}$ centile } & - & + & - & + & - & - \\
\hline \multicolumn{2}{|c|}{ Length at birth $<10^{\text {th }}$ centile } & - & + & - & + & N/A & N/A \\
\hline \multicolumn{2}{|c|}{ Growth: Short stature } & + & + & + & + & + & + \\
\hline \multicolumn{8}{|c|}{ Craniofacial features } \\
\hline \multirow[t]{3}{*}{ Eye } & Synophrys & - & + & - & + & - & + \\
\hline & Arched eyebrows & - & + & - & + & - & + \\
\hline & Long eyelashes & - & + & - & + & - & - \\
\hline \multirow[t]{2}{*}{ Nose } & Depressed nasal bridge & - & + & - & + & - & - \\
\hline & Anteverted nares & - & + & - & + & - & - \\
\hline \multirow[t]{3}{*}{ Philtrum } & Long & - & + & - & + & - & + \\
\hline & Prominent & - & + & - & + & - & - \\
\hline & Smooth & - & + & - & + & - & + \\
\hline \multirow[t]{4}{*}{ Mouth } & Thin upper lip & - & + & - & + & - & + \\
\hline & Down-slanting corners & - & + & - & + & - & - \\
\hline & Widely-spaced teeth & - & + & - & - & - & + \\
\hline & Micrognathia & + & + & + & + & + & + \\
\hline \multirow[t]{2}{*}{ Ear } & Low-set & + & + & + & + & - & - \\
\hline & Posteriorly rotated & - & + & - & + & - & - \\
\hline \multirow[t]{3}{*}{ Neck } & Low posterior hairline & + & + & + & + & - & - \\
\hline & Short neck & + & + & + & + & + & + \\
\hline & Webbed neck & + & - & + & - & - & - \\
\hline \multirow[t]{3}{*}{ Skull } & Microbrachycephaly & - & + & - & + & - & + \\
\hline & Bitemporal narrowing distance & - & + & - & + & - & + \\
\hline & Skull asymmetry with right-sided flattening & - & - & - & - & - & + \\
\hline \multicolumn{8}{|c|}{ Neurology and cognitive profile } \\
\hline \multicolumn{2}{|c|}{ Neurological involvement: Hypertonia } & - & + & - & + & N/A & N/A \\
\hline \multicolumn{2}{|c|}{ Cognitive: Mental retardation } & N/A & N/A & - & + & - & + \\
\hline \multicolumn{8}{|c|}{ Verbal and motor developmental delay } \\
\hline \multicolumn{2}{|c|}{ Speech delay } & + & + & + & + & + & + \\
\hline \multicolumn{2}{|c|}{ Language delay } & - & + & - & + & - & + \\
\hline \multicolumn{2}{|c|}{ Developmental delay } & - & + & - & + & - & + \\
\hline Musculos & eletal system & & & & & & \\
\hline Small $h$ & nds and/or feet & - & + & - & + & - & + \\
\hline $5^{\text {th }}$ fing & r clinodactyly & - & + & - & + & N/A & N/A \\
\hline Syndact & ly $3^{\text {rd }}-4^{\text {th }}$ fingers & - & - & - & - & - & + \\
\hline Proxima & ly placed thumb & - & + & - & + & - & + \\
\hline Single $p$ & almar crease & - & - & - & + & N/A & N/A \\
\hline Wide Sp & ace $1^{\text {st }} 2^{\text {nd }}$ toes & - & - & - & - & - & + \\
\hline Bilateral & cubitus valgus & - & - & + & - & N/A & N/A \\
\hline Limited & elbow extension & - & + & - & + & N/A & N/A \\
\hline Hip disl & cation & - & - & + & + & N/A & N/A \\
\hline
\end{tabular}


Table 1 Clinical data for patients with typical features of CdLS and TS (Continued)

\begin{tabular}{|c|c|c|c|c|c|c|}
\hline Short sternum & - & - & + & - & N/A & $\mathrm{N} / \mathrm{A}$ \\
\hline Scoliosis & - & - & - & - & + & + \\
\hline Bone age retardation & - & - & + & - & N/A & N/A \\
\hline Broad chest with widely-spaced nipples & + & - & + & - & + & - \\
\hline \multicolumn{7}{|l|}{ Ophthalmologic findings } \\
\hline Glaucoma & - & - & + & + & N/A & N/A \\
\hline Retinopathy & N/A & $\mathrm{N} / \mathrm{A}$ & - & + & $\mathrm{N} / \mathrm{A}$ & N/A \\
\hline Myopia & N/A & N/A & + & + & N/A & N/A \\
\hline \multicolumn{7}{|l|}{ ENT manifestations } \\
\hline Sensorineural hearing loss & N/A & $\mathrm{N} / \mathrm{A}$ & + & + & N/A & N/A \\
\hline \multicolumn{7}{|l|}{ Skin and nails } \\
\hline Lymphedema of the feet & - & - & + & - & - & - \\
\hline Hirsutism & - & + & - & + & - & - \\
\hline Cutis marmorata & - & - & - & + & $\mathrm{N} / \mathrm{A}$ & N/A \\
\hline Small and hypoplastic nails & + & - & + & - & - & - \\
\hline Hyperconvexed nails & - & - & - & - & + & - \\
\hline \multicolumn{7}{|l|}{ Cardiac system } \\
\hline ASD, VSD and PS & - & - & - & + & - & - \\
\hline Tetralogy of Fallot & - & - & - & - & - & + \\
\hline \multicolumn{7}{|l|}{ Gastrointestinal system } \\
\hline GERD & + & + & + & + & + & + \\
\hline Gastrointestinal malrotation & - & - & - & - & - & + \\
\hline Constipation & - & - & - & + & - & + \\
\hline Feeding problems & - & - & + & + & + & + \\
\hline Poor sucking and swallowing reflexes & + & - & + & - & $\mathrm{N} / \mathrm{A}$ & N/A \\
\hline
\end{tabular}

(+) Present; (-) Not present; N/A: Not available; OFC: Occipito-Frontal Circumference; ENT: Ear-Nose-Throat; ASV: Atrial Septal Defect; VSD: Ventricular Septal Defect; PS: Pulmonary Stenosis; GERD: Gastroesophageal Reflux Disease.

(Figures 3A and B). The parents' karyotypes were also examined and both were normal.

\section{Fluorescence in situ hybridization (FISH) analysis}

FISH analyses were performed on cultured peripheral blood lymphocytes and oral mucosa epithelial cells of the patient. Interphase nuclei were hybridized with commercial CEP X Spectrum Orange/Y Spectrum Green Direct Labeled Fluorescent DNA Probes (Abbott Molecular) according to the manufacturer's instructions. For each analysis, a minimum of 500 or 100 interphase nuclei from blood lymphocytes or oral mucosa epithelial cells were scored, respectively. FISH analyses confirmed the presence of $45, \mathrm{X} / 46, \mathrm{XX}$
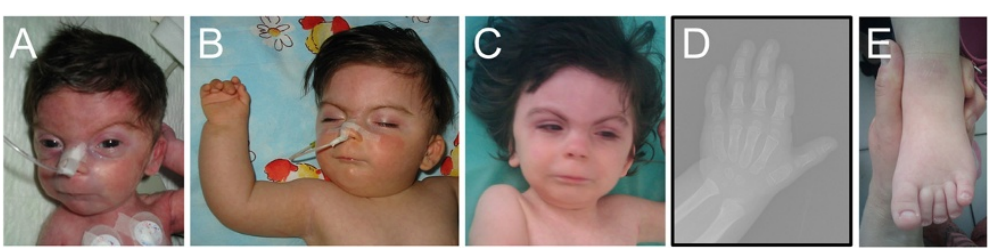

Figure 1 Phenotype of the patient. (A) Frontal view of the patient in the first week of life. (B) Frontal view and right hand of the patient at the age of 2 years and 10 months; and (C) at 3 years. (D) Roentgenogram of the left hand at the age of 3 years and 6 months and (E) left foot of the patient at the age of 3 years. Note typical CdLS facial features seen in our patient included synophrys, arched eyebrows, long eyelashes, depressed nasal bridge and anteverted nares, long and flat philtrum, thin upper lip, downslanting corners of the mouth, low set and posteriorly rotated ears and microbrachycephaly $(\mathbf{A}-\mathbf{C})$. Several mild musculoskeletal anomalies were noted including small hands and feet (D and $\mathbf{E})$, clinodactyly of the fifth finger and proximally placed thumb (D). 


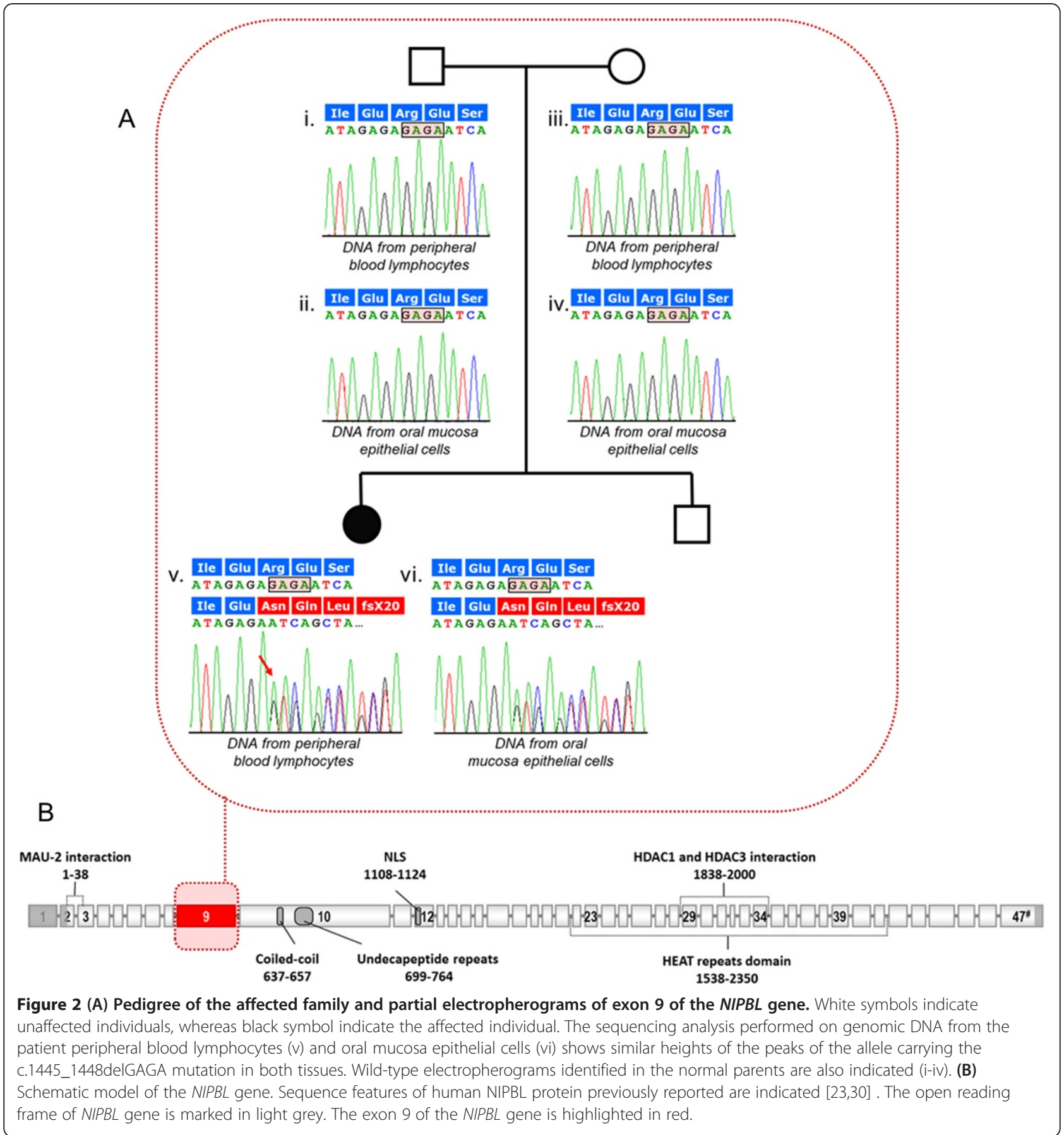

mosaicism in both tissues, with $28 \%$ and $7 \%$ of monosomy $\mathrm{X}$ in peripheral blood lymphocytes and buccal smears, respectively (Figures $3 \mathrm{C}-\mathrm{E}$ ).

\section{Discussion}

Here we report a patient with CdLS and a NIPBL frameshift mutation (c.1445_1448delGAGA deletion, p. Arg482AsnfsX20), who also had mosaic TS. Clinical diagnosis of CdLS was suspected from the typical craniofacial features, hirsutism, pre- and post-natal growth retardation, congenital heart defects and delayed psychomotor development with specific behavioural problems (Table 1). Following the scoring system for severity proposed by Kline et al. [2007] [16], she has a severe CdLS phenotype despite the mild anomalies of the upper limbs. In fact, the same NIPBL mutation was previously identified in another female with CdLS from Portugal, who had a similar phenotype [17]. Interestingly, our patient also showed 


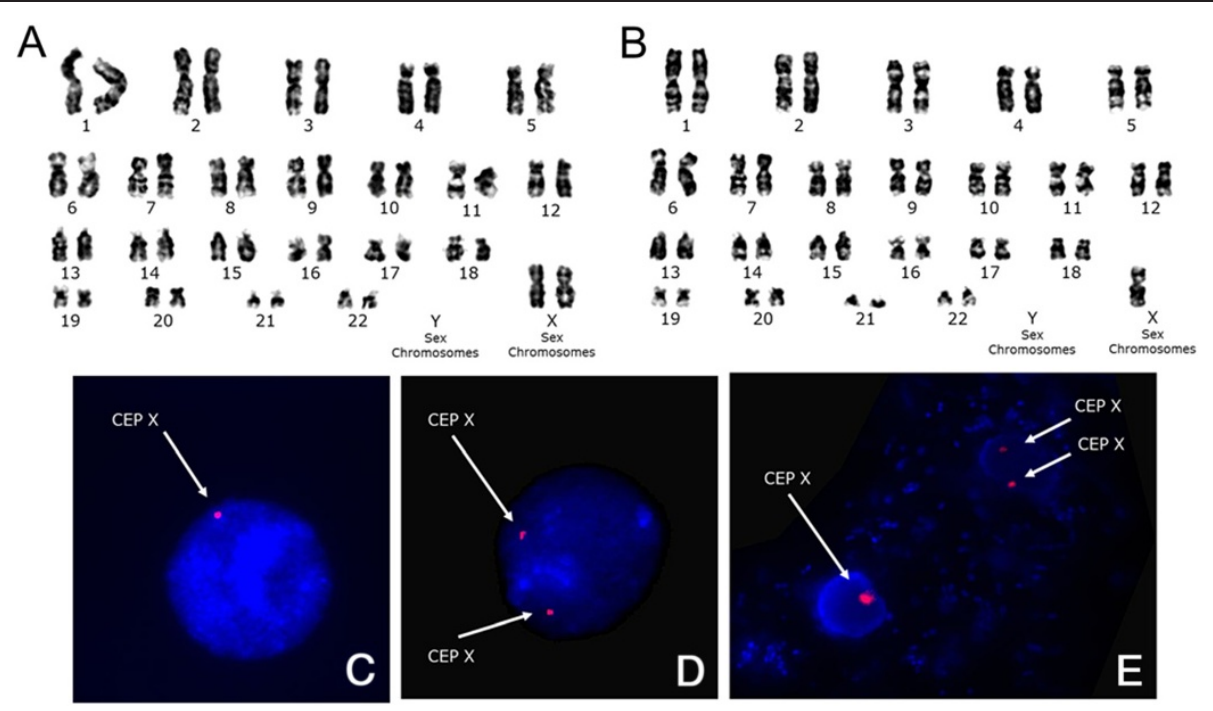

Figure 3 GTG-banded and FISH images from lymphocytes and buccal epithelial cells. Panels (A-B) show karyotypes of peripheral blood lymphocytes demonstrating the 45,X/46,XX mosaicism. Panels (C-E) show FISH analysis using CEP X Spectrum Orange/Y Spectrum Green Direct Labelled Fluorescent DNA probes from Abbott Molecular within of interphase nuclei of lymphocytes (C-D) and buccal epithelial cells (E). (C) and (E) show FISH interphase cells with one copy of the X chromosome (arrow). (D) and (E) show the presence of two copies of the X chromosomes (double arrows). Only representative cells with different karyotypes are shown here.

peripheral lymphedema and webbed neck in the neonatal period [10] (Table 1), suggesting the diagnosis of TS, which was subsequently confirmed by cytogenetic analysis.

Ophthalmologic findings have been reported in a high percentage of CdLS and TS patients. However, the congenital bilateral glaucoma diagnosed in our case has been described in only three patients with CdLS, and in three other patients with mosaic TS [18-20].

Congenital heart defects (CHD) are common both in TS (17-45\%) [10,21] and in CdLS (13-70\%) [16,22]. Our case has CHD that are common in CdLS (ASD, VSD and PS) but rarely seen in TS $(<0.5 \%)$ [16,21-23].

To date, only four patients with chromosomal rearrangements involving sex chromosomes have been reported in CdLS [12-15]. Only two of those cases had detailed clinical description and mosaic TS karyotype and could be compared to our patient [14,15] (Table 1).

The genotype of the first case, reported by Klosovskil et al. in 1968, is still unknown [14]. Like our patient she was diagnosed during childhood, and she also showed similar TS features and severe CdLS phenotype (Table 1).

More recently, Hoppman-Chaney et al. reported a female patient with a novel multi-exon deletion of the SMC1A gene, who showed an unusual, severe phenotype of CdLS and a mosaic monosomy X (35\% of peripheral blood lymphocytes) [15] (Table 1). Remarkably, her clinical findings related to mosaic TS were fewer and milder than in our patient. She had broad chest with wide-set nipples and hyperconvexed fingernails [15] (Table 1). This could be explained by the highly variable phenotypic expression of mosaic TS individuals [24]. Moreover, she also presented with atypical facial features for CdLS, such as prominent metopic suture, sparse hair, deep-set eyes and long and narrow earlobes [15]. She also showed severe typical features of classic CdLS, rarely seen in affected females with SMC1A mutations [3,15,23,25] (Table 1). This discrepancy could be due to the nature of her mutation, which causes severe protein dysfunction, similar to that caused by truncating mutations in the NIPBL gene $[3,15,23,25,26]$.

Molecular genetic analysis in our patient identified a de novo heterozygous frameshift mutation in exon 9 of the NIPBL gene (c.1445_1448delGAGA), resulting in a predicted stop codon and truncation of the translational product (p.R482NfsX20). Six additional truncating mutations have been found inside exon 9 [17,27], which is the second longest coding exon in NIPBL gene (627 base pairs). They are located within the N-terminal half of the protein, which is apparently only conserved in vertebrates and where most of the truncating mutations have been identified ( $70 \%$ vs $42 \%$ C-terminal half $)$. These data suggest this domain is important, although it has not yet been associated with any specific function [23].

$\mathrm{FISH}$ analyses of tissues from different germ layers revealed a low level of mosaicism for monosomy $\mathrm{X}$. However, the NIPBL mutation was identified in all the tissues analyzed, ruling out somatic mosaicism. These 
findings suggest that, ontogenically, the NIPBL mutation appeared earlier than the aneuploidy for the $\mathrm{X}$ chromosome.

Surprisingly, frameshift mutations in exon 9 of NIPBL have also been identified in some gastrointestinal cancers associated with chromosomal instability and aneuploidy [7,28,29]. It has been proposed that these mutations could alter chromosome segregation, the canonical role for the Cohesin complex, leading to chromosome imbalance with chromosome loss or gain $[25,28]$. This hypothesis may provide an explanation for the aneuploidy in our case, since a common cause of mosaicism is nondisjunction in an early postzygotic mitotic division. Hence, we suggest that the mutation in NIPBL could be the cause of the monosomy of the $\mathrm{X}$ chromosome. Moreover, this hypothesis would explain the numerous reports of individuals clinically diagnosed with CdLS who also carried a chromosomal abnormality $[11,15]$. Further experiments will be needed to confirm this association.

\section{Conclusions}

Here, we report a patient with CdLS due to a mutation in the NIPBL gene and mosaic TS. This patient showed the classical phenotype of CdLS, although without limb reduction. She was also clinically diagnosed with TS because of two typical recognizable features of the syndrome: the peripheral lymphedema and the webbed neck. Molecular characterization showed that the NIPBL mutation was present in all the tissues analyzed from different embryonic origins (mesoderm and ectoderm), while FISH analyses revealed that the mosaicism for the monosomy of the $\mathrm{X}$ chromosome was tissue specific. These findings indicate that, ontogenically, the NIPBL mutation appeared before the monosomy X. Moreover, the recent identification of frameshift mutations in exon 9 of the NIPBL gene in colon cancer cells associated with chromosome aneuploidy suggests that the NIPBL mutation could contribute to the loss of the X chromosome [28].

\section{Consent}

The manuscript was written with the approval of Independent Bioethics Committee for Clinical Research, Medical University of Gdańsk. Written informed consent was obtained from the patient's parents for publication of this case report and any accompanying images. A copy of the written consent is available for review by the Series Editor of this journal.

\section{List of abbreviations}

CdLS: Cornelia de Lange syndrome; TS: Turner syndrome; OFC: OccipitoFrontal Circumference; ENT: Ear-Nose-Throat; ASV: Atrial Septal Defect; VSD: Ventricular Septal Defect; PS: Pulmonary Stenosis;

GERD: Gastroesophageal Reflux Disease; ABR: Auditory Brainstem Response;
IgA-TTG: IgA anti-tissue transglutaminase antibody; IgA-EmA: IgA antiendomysial antibody; CHD: Congenital Heart Defect.

\section{Competing interests}

The authors declare that they have no competing interests.

\section{Authors' contributions}

$J W, J L, F G H$ and JP participated in the conception and the design of the study. MCGR and BP designed and interpreted the molecular evaluations. MCGR, MA and METR conducted the molecular analyses. DW performed cytogenetic and FISH analyses. JW, AP and FJR examined the patient, collected the data relevant to this case report and made the clinical diagnosis of the patient. JW, MCGR and JP reviewed the literature and wrote the MS. All the authors have read, revised and approved the final version of the manuscript.

\section{Acknowledgements}

We sincerely thank the patient's family for participating in this study. We thank Rebeca Escosa Vela, who provided technical support. This study was funded by grants from: The Polish Ministry of Science and Higher Education (Ref\# N 407020 32/0536); The Spanish Ministry of Health - Fondo de Investigación Sanitaria (FIS) (Ref.\# PI09-1422); the Diputación General de Aragón (DGA) (Grupo Consolidado B20), European Social Fund ("Construyendo Europa desde Aragón") and University of Zaragoza (Ref.\# PIFUZ_2009-BIO-02).

\section{Author details}

${ }^{1}$ Department of Pediatrics, Hematology, Oncology and Endocrinology, Department of General Nursery, Medical University of Gdańsk, Gdańsk Poland. 'Unit of Clinical Genetics and Functional Genomics, Departments of Pharmacology-Physiology and Pediatrics, Medical School, University of Zaragoza, and Institute of Health Sciences of Aragón, Zaragoza, Spain. ${ }^{3}$ Department of Pediatrics, Hematology and Oncology, Children University Hospital, Lublin, Poland. ${ }^{4}$ Department of Biochemistry, School of Pharmacy, University of Barcelona, and Ciber-Obn, Health Institute Carlos III, Barcelona, Spain. ${ }^{5}$ Department of Biology and Genetics, Medical University of Gdańsk, Gdańsk, Poland. 'Unit of Clinical Genetics and Functional Genomics, Department of Pharmacology and Physiology, University of Zaragoza, Medical School, c/Domingo Miral s/n, Zaragoza E-50009, Spain.

Received: 17 January 2012 Accepted: 24 May 2012

Published: 7 June 2012

\section{References}

1. Ireland M, Donnai D, Burn J: Brachmann-de Lange syndrome. Delineation of the clinical phenotype. Am J Med Genet 1993, 47(7):959-964.

2. Barisic I, Tokic V, Loane M, Bianchi F, Calzolari E, Garne E, Wellesley D, Dolk $\mathrm{H}$ : Descriptive epidemiology of Cornelia de Lange syndrome in Europe. Am J Med Genet A 2008, 146A(1):51-59.

3. Deardorff MA, Kaur M, Yaeger D, Rampuria A, Korolev S, Pie J, Gil-Rodriguez C, Arnedo M, Loeys B, Kline AD, Wilson M, Lillquist K, Siu V, Ramos FJ, Musio A, Jackson LS, Dorsett D, Krantz ID: Mutations in cohesin complex members SMC3 and SMC1A cause a mild variant of Cornelia de Lange syndrome with predominant mental retardation. Am J Hum Genet 2007, 80(3):485-494.

4. Krantz ID, McCallum J, DeScipio C, Kaur M, Gillis LA, Yaeger D, Jukofsky L, Wasserman N, Bottani A, Morris CA, Nowaczyk MJ, Toriello H, Bamshad MJ, Carey JC, Rappaport E, Kawauchi S, Lander AD, Calof AL, Li HH, Devoto M, Jackson LG: Cornelia de Lange syndrome is caused by mutations in NIPBL, the human homolog of Drosophila melanogaster Nipped-B. Nat Genet 2004, 36(6):631-635.

5. Tonkin ET, Wang TJ, Lisgo S, Bamshad MJ, Strachan T: NIPBL, encoding a homolog of fungal Scc2-type sister chromatid cohesion proteins and fly Nipped-B, is mutated in Cornelia de Lange syndrome. Nat Genet 2004, 36(6):636-641.

6. Musio A, Selicorni A, Focarelli ML, Gervasini C, Milani D, Russo S, Vezzoni P, Larizza L: X-linked Cornelia de Lange syndrome owing to SMC1L1 mutations. Nat Genet 2006, 38(5):528-530.

7. Liu J, Krantz ID: Cornelia de Lange syndrome, cohesin, and beyond. Clin Genet 2009, 76(4):303-314. 
8. Saenger P, Wikland KA, Conway GS, Davenport M, Gravholt $\mathrm{CH}$, Hintz R, Hovatta O, Hultcrantz M, Landin-Wilhelmsen K, Lin A, Lippe B, Pasquino AM, Ranke MB, Rosenfeld R, Silberbach M: Recommendations for the Diagnosis and Management of Turner syndrome. J Clin Endocrinol Metab 2001, 86(7):3061-3069

9. Ranke MB, Saenger P: Turner's syndrome. Lancet 2001, 358(9278):309-314

10. Bondy CA: Care of girls and women with Turner syndrome: a guideline of the Turner syndrome study group. J Clin Endocrinol Metab 2007, 92(1):10-25.

11. DeScipio C, Kaur M, Yaeger D, Innis JW, Spinner NB, Jackson LG, Krantz ID: Chromosome rearrangements in Cornelia de Lange syndrome (CdLS): Report of a der(3)t(3;12)(p25.3;p13.3) in two half sibs with features of CdLS and review of reported CdLS cases with chromosome rearrangements. Am J Med Genet A 2005, 137A(3):276-282.

12. Calo S, Gualandri W, Radice C: XY-XO mosaicism in a case of Cornelia de Lange syndrome. Minerva Pediatr 1968, 20(50):2600-2604.

13. Beck B, Mikkelsen M: Chromosomes in the Cornelia de Lange syndrome. Hum Genet 1981, 59(4):271-276

14. Klosovskili BN, lankova MF, Fateeva EM, Damanskaia L: On the problem of the De Lange's syndrome. Pediatriia 1968, 47(8):33-39.

15. Hoppman-Chaney N, Jang JS, Jen J, Babovic-Vuksanovic D, Hodge JC: Inframe multi-exon deletion of SMC1A in a severely affected female with Cornelia de Lange syndrome. Am J Med Genet A 2012, 158A(1):193-198.

16. Kline AD, Krantz ID, Sommer A, Kliewer M, Jackson LG, FitzPatrick DR, Levin AV, Selicorni A: Cornelia de Lange syndrome: clinical review, diagnostic and scoring systems, and anticipatory guidance. Am J Med Genet A 2007, 143A(12):1287-1296.

17. Oliveira J, Dias C, Redeker E, Costa E, Silva J, Reis Lima M, den Dunnen JT, Santos R: Development of NIPBL locus-specific database using LOVD: from novel mutations to further genotype-phenotype correlations in Cornelia de Lange Syndrome. Hum Mutat 2010, 31(11):1216-1222.

18. Lloyd IC, Haigh PM, Clayton-Smith J, Clayton P, Price DA, Ridgway AE, Donnai D: Anterior segment dysgenesis in mosaic Turner syndrome. $\mathrm{Br} J$ Ophthalmol 1997, 81(8):639-643.

19. Nallasamy S, Kherani F, Yaeger D, McCallum J, Kaur M, Devoto M, Jackson LG, Krantz ID, Young TL: Ophthalmologic findings in Cornelia de Lange syndrome: a genotype-phenotype correlation study. Arch Ophthalmol 2006, 124(4):552-557.

20. Lee WB, Brandt JD, Mannis MJ, Huang CQ, Rabin GJ: Aniridia and Brachmann-de Lange syndrome: a review of ocular surface and anterior segment findings. Cornea 2003, 22(2):178-180.

21. Gravholt $\mathrm{CH}$ : Epidemiological, endocrine and metabolic features in Turner syndrome. Eur J Endocrinol 2004, 151(6):657-687.

22. Selicorni A, Colli AM, Passarini A, Milani D, Cereda A, Cerutti M, Maitz S, Alloni V, Salvini L, Galli MA, Ghiglia S, Salice P, Danzi GB: Analysis of Congenital Heart Defects in 87 consecutive patients with Brachmann-de Lange syndrome. Am J Med Genet A 2009, 149A(6):1268-1272.

23. Pie J, Gil-Rodriguez MC, Ciero M, Lopez-Vinas E, Ribate MP, Arnedo M, Deardorff MA, Puisac B, Legarreta J, de Karam JC, Rubio E, Bueno I, Baldellou A, Calvo MT, Casals N, Olivares JL, Losada A, Hegardt FG, Krantz ID, GómezPuertas $P$, Ramos FJ: Mutations and variants in the cohesion factor genes NIPBL, SMC1A, and SMC3 in a cohort of 30 unrelated patients with Cornelia de Lange syndrome. Am J Med Genet A 2010, 152A(4):924-929.

24. Sybert VP, McCauley E: Turner's syndrome. N Engl J Med 2004, 351(12):1227-1238.

25. Mannini L, Liu J, Krantz ID, Musio A: Spectrum and consequences of SMC1A mutations: the unexpected involvement of a core component of cohesin in human disease. Hum Mutat 2010, 31(1):5-10.

26. Yan J, Saifi GM, Wierzba TH, Withers M, Bien-Willner GA, Limon J, Stankiewicz P, Lupski JR, Wierzba J: Mutational and genotype-phenotype correlation analyses in 28 Polish patients with Cornelia de Lange syndrome. Am J Med Genet A 2006, 140(14):1531-1541.

27. Gillis LA, McCallum J, Kaur M, DeScipio C, Yaeger D, Mariani A, Kline AD, Li HH, Devoto M, Jackson LG, Krantz ID: NIPBL mutational analysis in 120 individuals with Cornelia de Lange syndrome and evaluation of genotype-phenotype correlations. Am J Hum Genet 2004, 75(4):610-623.

28. Barber TD, McManus K, Yuen KW, Reis M, Parmigiani G, Shen D, Barrett I, Nouhi Y, Spencer F, Markowitz S, Velculescu VE, Kinzler KW, Vogelstein B, Lengauer C, Hieter P: Chromatid cohesion defects may underlie chromosome instability in human colorectal cancers. Proc Natl Acad Sci U S A 2008, 105(9):3443-3448.
29. Barbero JL: Sister chromatid cohesion control and aneuploidy. Cytogenet Genome Res 2011, 133(2-4):223-233.

30. Braunholz D, Hullings $M$, Gil-Rodriguez MC, Fincher $C T$, Mallozzi MB, Loy $E_{t}$ Albrecht M, Kaur M, Limon J, Rampuria A, Clark D, Kline A, Dalski A, Eckhold J, Tzschach A, Hennekam R, Gillessen-Kaesbach G, Wierzba J, Krantz ID, Deardorff MA, Kaiser FJ: Isolated NIPBL missense mutations that cause Cornelia de Lange syndrome alter MAU2 interaction. Eur J Hum Genet 2012, 20(3):271-276.

doi:10.1186/1471-2350-13-43

Cite this article as: Wierzba et al:: Cornelia de Lange syndrome with NIPBL mutation and mosaic Turner syndrome in the same individual. BMC Medical Genetics 2012 13:43.

\section{Submit your next manuscript to BioMed Central and take full advantage of:}

- Convenient online submission

- Thorough peer review

- No space constraints or color figure charges

- Immediate publication on acceptance

- Inclusion in PubMed, CAS, Scopus and Google Scholar

- Research which is freely available for redistribution

Submit your manuscript at www.biomedcentral.com/submit
C) Biomed Central 